\title{
Law Enforcement in Indonesia's Exclusive Economic Zone in the Framework of Indonesia's National Interest in the Marine Sector
}

\author{
Bambang S. Irianto; Made Warka; Otto Yudianto
}

Faculty of Law, Universitas 17 Agustus 1945 Surabaya, Indonesia

http://dx.doi.org/10.18415/ijmmu.v8i9.3010

\begin{abstract}
For law enforcement in the IEEZ in the context of Indonesia's national interest in the marine sector, the Indonesian Navy, the Maritime Security Agency (Bakamla), and the Ministry of Maritime Affairs and Fisheries (KKP) have carried out the execution of the sinking of foreign fishing vessels caught carrying out illegal fishing practices in the territorial waters Indonesia. This policy is intended as a stern warning to the perpetrators of illegal fishing as well as a form of Indonesia's commitment in monitoring and enforcing the law in Indonesian marine areas, which will continue to be carried out in order to have a deterrent effect on the perpetrators. However, the act of catching foreign fishing vessels is carried out, still based on the applicable rules and regulations, as well as the fulfillment of sufficient initial evidence. Sufficient preliminary evidence to arrest a foreign-flagged fishing vessel is evidence that suspects a criminal act in the field of fisheries by a foreign-flagged fishing vessel.
\end{abstract}

Keywords: Marine; Enforcement; National

\section{Introduction}

Juridically normative, there is the United Nations Convention on the International Law of the Sea in 1982 which has been ratified by Law of the Republic of Indonesia Number 17 of 1985 concerning Ratification of the 1982 United Nations Convention on the Law of the Sea (UNCLOS) which places Indonesia as having sovereign rights to utilize, conserve and manage fish resources in the Indonesian Exclusive Economic Zone (IEEZ) and the high seas which is carried out based on applicable international requirements or standards. The exclusive economic zone has a special legal status that is sui generia and sui juris (Boer Mauna, 2001) which means that from the legal point of view the IEEZ area in this case cannot be equated with legal treatment in the territorial area which is the sovereign territory of a country. If we look further at the legal relevance of the territorial potential of the Indonesian sea, then of course we will understand the legal theory of sovereignty which is closely related to the legal understanding of positivism, because it is this positivism legal understanding that discusses this issue a lot. Therefore, it's not surprising that the issue of sovereignty is widely discussed in books written by adherents of legal positivism, such as those by HLA Hart, Hans Kalsen, Friedman and Lon Fuller.

In addition, at the level of law and international relations related to diplomacy between countries, of course the state must put forward the theory of state jurisdiction, where every sovereign state must have 
jurisdiction, therefore jurisdiction will relate to the power of a state. Jurisdiction is the main and central feature of state sovereignty, because it is the exercise of authority that can change or create or terminate legal relations and obligations. By looking at the theory of sovereignty and the theory of jurisdiction(Mochtar, 1996), then of course at the case level, the EEZ is a part of marine waters located outside of and bordering the territorial sea as wide as 200 (two hundred) sea miles measured from the baseline from which the width of the territorial sea be measured. The coastal state only has sovereign rights and jurisdiction that are exclusive to its EEZ. This is a legal problem when there is damage to marine resources, especially in the field of fisheries in the EEZ by looking at the potential that exists in Indonesia and the potential for fisheries crime. Fisheries crime is a crime and a violation of the provisions of the law governing the management and fish resources in the fisheries management area of the Republic of Indonesia (WPPRI).(Fauzi, n.d.)

By looking at the above, legal problems arise in this study, including: (1) how is law enforcement in the Indonesian Exclusive Economic Zone (IEEZ) in the context of Indonesia's national interest in the marine sector; (2) the imposition of criminal sanctions for foreign fishing vessels that commit illegal fishing crimes in the Indonesian Exclusive Economic Zone (IEEZ) according to Law No. 45 of 2009 concerning Fisheries.

\section{Research Methods}

This research uses normative juridical. (Novianto et al., 2020)

\section{Results and Discussion}

\section{Law Enforcement in The Indonesian Exclusive Economic Zone in the Context of Indonesia's National Interest in the Maritime Sector}

In terms of fisheries management, there are several international agreements that are oriented towards balance and sustainable and sustainable use. These agreements include(Bangun, n.d.): First, the Code of Conduct for Responsible Fisheries (CCRF). The Committee of the Food and Agriculture Organization (FAO) on fisheries at its 19th session, March 1991, developed a concept that leads to sustainable and responsible fisheries management. FAO recommends the formulation of responsible fisheries management known as CCRF and established in October 1995 to assist fish-producing countries, especially developing countries. The CCRF is a guideline for national and international efforts to ensure the sustainable exploitation of aquatic living resources, which are in harmony and in harmony with the environment.

Second, the Indian Ocean Tuna Commission (IOTC), an intergovernmental organization under the auspices of the Food and Agricultural Organization (FAO) which is mandated to regulate various species of tuna in the Indian Ocean and adjacent seas. The aim of the IOTC is to develop cooperation between member countries through appropriate arrangements so as to encourage the conservation and optimum utilization of tuna stocks and encourage sustainable development in the field of fisheries.

Law enforcement at the level of the law of the sea convention that regulates the potential of fishery resources internationally is regulated by UNCLOS 1982 in relation to the utilization and management of fish resources.(Jamilah \& Disemadi, 2020) The 1982 Law of the Sea Convention contains provisions relating to fisheries law applicable in different types of maritime zones under and outside the boundaries of national jurisdiction. The provisions of Chapter $\mathrm{V}$ of this Convention contain legal arrangements for fisheries under the exclusive economic zone (EEZ) regime, the exclusive economic zone of two or more coastal countries and the high seas. Law No. 45 of 2009 concerning Amendments to Law No. 31 of 2004 concerning Fisheries. (Silviani, 2019) 
In relation to illegal fishing arrangements carried out by foreign fishing vessels in the Indonesian Exclusive Economic Zone according to the Law of the Republic of Indonesia No. 45 of 2009 concerning amendments to the Republic of Indonesia Law No. 31 of 2004 concerning fisheries, it's stated in Article 93 paragraph (2), namely "Everyone who owns and or operates a fishing vessel with a foreign flag is fishing in the Indonesian Exclusive Economic Zone (IEEZ) which doesn't have SIPI as referred to in Article 27 paragraph (2), imprisoned with a maximum imprisonment of 6 (six) years and a maximum fine of Rp. 20,000,000,000.- (twenty billion rupiah)."

\section{Imposition of Criminal Sanctions for Foreign Fishing Vessels Conducting Criminal Acts of Illegal Fishing in the Indonesian Exclusive Economic Zone according to Law No. 45 of 2009 Concerning Fisheries}

With the support of the theory of punishment, law enforcement and increasing security in the Indonesian seas (Indonesian waters and the Exclusive Economic Zone) which covers an area of 6 million $\mathrm{km} 2$ (3 times the land area) still require great and intensive attention from state security tools. Law enforcement and security schemes in the Indonesian Archipelagic Sea Lane (ALKI) need to be improved. (Bateman, 2007)

The complexity of maritime security issues and problems in Southeast Asia has become the concern of ASEAN countries which has encouraged the establishment of the ASEAN Maritime Forum $(A M F)$.(Bueger, n.d.) Criminal Sanctions for Foreign Citizens who commit theft of fish in the IEEZ area. Criminal sanctions can be included in the stage of applying sanctions in criminal law and also providing sanctions in criminal law.(H A S et al., 2020) Jan Remmelink uses the term criminal imposition with punishment, namely the conscious and mature imposition by the competent authority on perpetrators who are guilty of violating a rule of law. Complicated problems if there is fishing, they can be accused of stealing fish in Indonesian territory, then fleeing to Malaysian territory, on the contrary stealing fish in Malaysian territory and fishermen fleeing to Indonesian territory, because the narrow strait contains many fish in the Malacca Strait, which are located on three national borders, namely Singapore, Malaysia, and Indonesia.(Elliott, n.d.) Where this strait is an important route in the shipping sector, but often happens, problems in this strait have an impact on the surrounding coastal countries. As it's known that, since 1967, especially since the outbreak of the Arab-Israeli War, giant tankers began to be born. Many of these tankers carry oil from the Middle East to Japan.

Sentences for perpetrators of fisheries crimes in IEEZ waters include: The coastal state can apply all provisions of the criminal law code to ships. The error caused a security disturbance in the coastal state. In this case, the wrong processing and utilization of the country's living natural resources, can impose penalties in accordance with the provisions.

The jurisdictional right of the State of the waters can manage and utilize the living natural resources in the IEEZ and the State of the waters has the authority to carry out legal proceedings up to court against foreign ships, in accordance with the provisions of applicable international law.(Sudini, 2015) Captured ships and their crew are immediately released after appropriate replacement or other forms. An archipelagic state may not carry out detention, confinement, if there is no agreement from the state that makes international treaties. The archipelagic state must immediately inform the flag state ship about the sanctions and consequences of the punishment to be given or decided by the coastal state ("Article 73 paragraph (1) UNCLOS 1982”).

\section{Conclusion}

For law enforcement in the IEEZ in the context of Indonesia's national interest in the marine sector, the Indonesian Navy, the Maritime Security Agency (Bakamla), and the Ministry of Maritime Affairs and 
Fisheries (KKP) have carried out the execution of the sinking of foreign fishing vessels caught carrying out illegal fishing practices in the territorial waters Indonesia. This policy is intended as a stern warning to the perpetrators of illegal fishing as well as a form of Indonesia's commitment in monitoring and enforcing the law in Indonesian marine areas, which will continue to be carried out in order to have a deterrent effect on the perpetrators. However, the act of catching foreign fishing vessels is carried out, still based on the applicable rules and regulations, as well as the fulfillment of sufficient initial evidence. Sufficient preliminary evidence to arrest a foreign-flagged fishing vessel is evidence that suspects a criminal act in the field of fisheries by a foreign-flagged fishing vessel.

For the imposition of criminal sanctions for foreign fishing vessels that commit illegal fishing crimes in the IEEZ 45 of 2009 concerning Fisheries has been carried out jointly by the Directorate for Handling Violations, the Directorate General of Supervision of Marine Resources and Fisheries, the Ministry of Maritime Affairs and Fisheries, since 2014, in the form of the implementation of the sinking of foreign ships that are perpetrators of the crime of illegal fishing, always through the mechanism of the provisions of Article 76A Law Number 45 of 2009 concerning Amendments to Law Number 31 of 2004 concerning Fisheries in conjunction with Article 38 jo. Article 45 of Law Number 8 of 1981 a mechanism regulated that objects and/or tools used in and/or resulting from criminal acts of fisheries can be confiscated for the state or destroyed after obtaining approval from the Head of the District Court, and based on a court decision that has permanent legal force (inkracht) as regulated in Law Number 8 of 1981.

\section{References}

Bangun, B. H. (n.d.). Konsepsi dan Pengelolaan Wilayah Perbatasan Negara.

Bateman, S. (2007). UNCLOS and its limitations as the foundation for a regional maritime security regime. Korean Journal of Defense Analysis, 19(3). https://doi.org/10.1080/10163270709464140

Boer Mauna. (2001). Hukum Internasional Pengertian Peranan Dan Fungsi Dalam Era Dinamika Global. P.T. Alumni.

Bueger, C. (n.d.). What is Maritime Security. Forthcoming in Marine Policy.

Elliott, B. (n.d.). Recent Articels on Overfishing in The Philippines Shed Ligth onOceana's Save the Oceans, feed the World' Campaign.

Fauzi, A. (n.d.). Kebijakan Perikanan dan Kelautan.

H A S, Y. N. A., Soelistyo, L. T. D., \& Agustin, I. S. U. N. (2020). PENGELOLAAN KEKAYAAN HAYATI DI KAWASAN “THE AREA” MENURUT UNCLOS 1982 [STUDI TENTANG NODUL POLIMETALIK (POLYMETALLIC NODULES)]. Jurnal Hukum Bisnis Bonum Commune. https://doi.org/10.30996/jhbbc.v3i1.3073.

Jamilah, A., \& Disemadi, H. S. (2020). Penegakan Hukum Illegal Fishing dalam Perspektif UNCLOS 1982. Mulawarman Law Review. https://doi.org/10.30872/mulrev.v5i1.311.

Mochtar, K. (1996). Pengantar Hukum Internasional. Binacipta.

Novianto, R. D., Firmansyah, D. A., \& Pratama, N. A. (2020). PENYELESAIAN SENGKETA DI LAUT NATUNA UTARA. Jurnal Hukum Bisnis Bonum Commune. https://doi.org/10.30996/jhbbc.v3i1.3074 
Silviani, N. Z. (2019). Interpretasi Perjanjian Internasional Terkait Historical Rights Dalam UNCLOS 1982. Jurnal Selat, 6(2). https://doi.org/10.31629/selat.v6i2.1067.

Sudini, L. P. (2015). Pengelolaan Pencemaran Laut Di Indonesia (3rd ed.). R.A. De Rozarie.

\section{Copyrights}

Copyright for this article is retained by the author(s), with first publication rights granted to the journal.

This is an open-access article distributed under the terms and conditions of the Creative Commons Attribution license (http://creativecommons.org/licenses/by/4.0/). 